\title{
Effects of the application of therapeutic massage in children with cancer: a systematic review
}

\author{
Juan Rodríguez-Mansilla ${ }^{1}$ \\ Blanca González-Sánchez ${ }^{1}$ \\ Silvia Torres-Piles ${ }^{1}$ \\ Jorge Guerrero Martín ${ }^{1}$ \\ María Jiménez-Palomares² \\ Macarena Núñez Bellino ${ }^{3}$
}

\begin{abstract}
Objective: to learn about the effects of the use of therapeutic massage in children with cancer. Method: systematic review of controlled clinical trials The search was conducted in November 2014 in the following databases: Pubmed, CSIC, Dialnet, Scopus, Cochrane and PEDro. Inclusion criteria were: clinical trials, published in English or Spanish, analyzing the effects of massage on the different stages and types of childhood cancer (between 1 and 18 years old). Results: of 1007 articles found, 7 met the inclusion criteria. Their authors use different massage techniques (Swedish massage, effleurage, petrissage, frictions, pressures), obtaining benefits in the symptoms present during the illness (decrease of pain, nausea, stress, anxiety and increase of white blood cells and neutrophils). Conclusion: therapeutic massage improves the symptoms of children with cancer, but there is a need for more research that may support the effects attributed to it.
\end{abstract}

Descriptors: Child; Massage; Anxiety; Neoplasia; Leukemia; Cancer.

\footnotetext{
PhD, Professor, Facultad de Medicina, Universidad de Extremadura, Badajoz, Extremadura, Spain.

2 PhD, Professor, Facultad de Enfermería y Terapia Ocupacional, Universidad de Extremadura, Caceres, Extremadura, Spain.

3 Physical Therapist.
}

\section{How to cite this article}

Rodríguez-Mansilla J, González-Sánchez B, Torres-Piles S, Guerrero Martín J, Jiménez-Palomares M, Núñez Bellino M. Effects of the application of therapeutic massage in children with cancer: a systematic review. Rev. Latino-Am. Enfermagem. 2017;25:e2903. [Access_f_] ; Available in: org/10.1590/1518-8345.1774.2903. month day year DOI: http://dx.doi. 


\section{Introduction}

Cancer is defined as "a group of diseases in which the body produces an excess of malignant cells with typical traits of behavior and uncontrolled growth"(1).

It is currently considered the second cause of death between the ages of 1 and 14, with a higher incidence in developed countries ${ }^{(2-3)}$, being leukemia the majority of the infantile cases. According to medical evidence, the most frequent are acute lymphoblastic leukemia (ALL), Central Nervous System (CNS) tumors, lymphomas (Hodgkin's and non-Hodgkin's), Sympathetic Nervous System (SNS) and bone tumors ${ }^{(1)}$.

The treatment of this pathology in conventional protocols use isolated or combined ${ }^{(4-6)}$. antineoplastic drugs, radiotherapy and surgery according to the type ${ }^{(1)}$.

The application of the massage comes from the oldest civilizations ${ }^{(7-8)}$. In the middle of the XIX century its effectiveness was demonstrated delimiting its therapeutic indications ${ }^{(8)}$. It can be defined( ${ }^{(9)}$ as "a set of manipulations and / or maneuvers performed with the hands of the therapist and applied to the human body with preventive, hygienic, therapeutic, rehabilitating and psychological objectives in a methodical, orderly and reasoned manner". It consists of the basic maneuvers of: effleurage, petrissage, friction, pinching and vibration ${ }^{(9)}$.

Some authors ${ }^{(10)}$ show that the perception of pain by palliative care patients decreases and this effect lasts up to 18 hours after application, while others ${ }^{(11)}$ indicate that the intervention performed by a nurse specialized in therapeutic massage for 45 minutes in children with bone metastases reduces anxiety and pain, with lasting effects in the long term.

Would it be possible to improve the symptomatology of patients through the application of therapeutic massage? Due the above, the purpose of this review is to know the effects of the application of therapeutic massage on the oncological children population.

\section{Method}

Systematic review of controlled clinical trials.

Inclusion criteria:

-Articles in English / Spanish.

-Published from 11/01/1994 to 11/01/2014.

-Oncological children patients aged $0.5-18$ years.

-Addressing different types of childhood cancer.

-Articles who use therapeutic massage or some of their basic maneuvers as treatment.

Exclusion criteria:

-Articles that do not correspond to the type of study analyzed.

-Research that addresses types of cancer other than childhood cancer.

-Studies that do not address therapeutic massage in treatment.

\section{Search strategy}

The search was conducted in November 2014 in Pubmed, Cochrane, CSIC, Scopus, PEDro and Dialnet. The combinations of terms Mesh: "cancer AND child AND massage" were used; "Chemotherapy AND child AND massage"; "Cancer AND child AND touch"; "Cancer AND pediatric AND massage"; "Pediatric AND cancer AND touch"; "Cancer AND anxiety AND massage AND children"; "Leukemia AND child AND massage"; "Neoplasm AND pediatric AND massage".

\section{Selection of studies}

A selection of complete articles was established by reading the title and abstract. Those articles meeting the inclusion criteria were subjected to a complete reading for analysis and inclusion. The methodological quality was analyzed using the Physiotherapy Evidence Database scale(12).

\section{Methodological quality}

See Figure 1.

\begin{tabular}{|c|c|c|c|c|c|c|c|c|c|c|c|c|}
\hline Article & $1^{*}$ & $2^{\dagger}$ & $3^{\ddagger}$ & $4^{\S}$ & $5^{\|}$ & $6 \pi$ & $7^{\star *}$ & $8^{t+}$ & $9 \neq$ & $10^{\S s}$ & $11^{111 I}$ & points \\
\hline Phipps S et al. ${ }^{(13)}(2012)$ & Yes & Yes & No & Yes & No & No & No & No & Yes & Yes & Yes & 5 (Fair) \\
\hline Post-White J et al. ${ }^{(14)}$ (2009) & Yes & Yes & No & Yes & No & No & No & No & Yes & Yes & Yes & 5 (Fair) \\
\hline Haun JN et al. ${ }^{(15)}(2009)$ & No & Yes & No & No & No & No & No & Yes & Yes & Yes & Yes & 5 (Fair) \\
\hline Field T et al. ${ }^{(16)}(2001)$ & No & Yes & No & Yes & No & No & No & Yes & Yes & Yes & No & 5 (Fair) \\
\hline Mazlum S et al. ${ }^{(17)}(2013)$ & Yes & Yes & No & Yes & No & No & No & Yes & Yes & Yes & Yes & 6 (Good) \\
\hline Batalha LM et al. ${ }^{(18)}(2013)$ & Yes & Yes & No & Yes & No & No & Yes & Yes & Yes & Yes & Yes & 7 (Good) \\
\hline Mehling WE et al. ${ }^{(19)}(2012)$ & No & Yes & Yes & Yes & No & No & No & Yes & Yes & Yes & Yes & 7 (Good) \\
\hline
\end{tabular}

*1:Specification of eligibility criteria; $\uparrow 2:$ Random assignment; $¥ 3$ :Hidden allocation; §4:Groups similar at start; ॥5: Masking of patients; $\uparrow 6:$ Masking of the therapists; **7:Masking

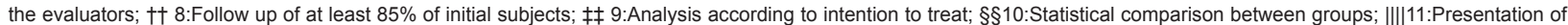
timely measures and variability of key results.

Figure 1 - Methodological quality of included studies. Badajoz, EX, Spain, 2016 


\section{Results}

See Figure 2.

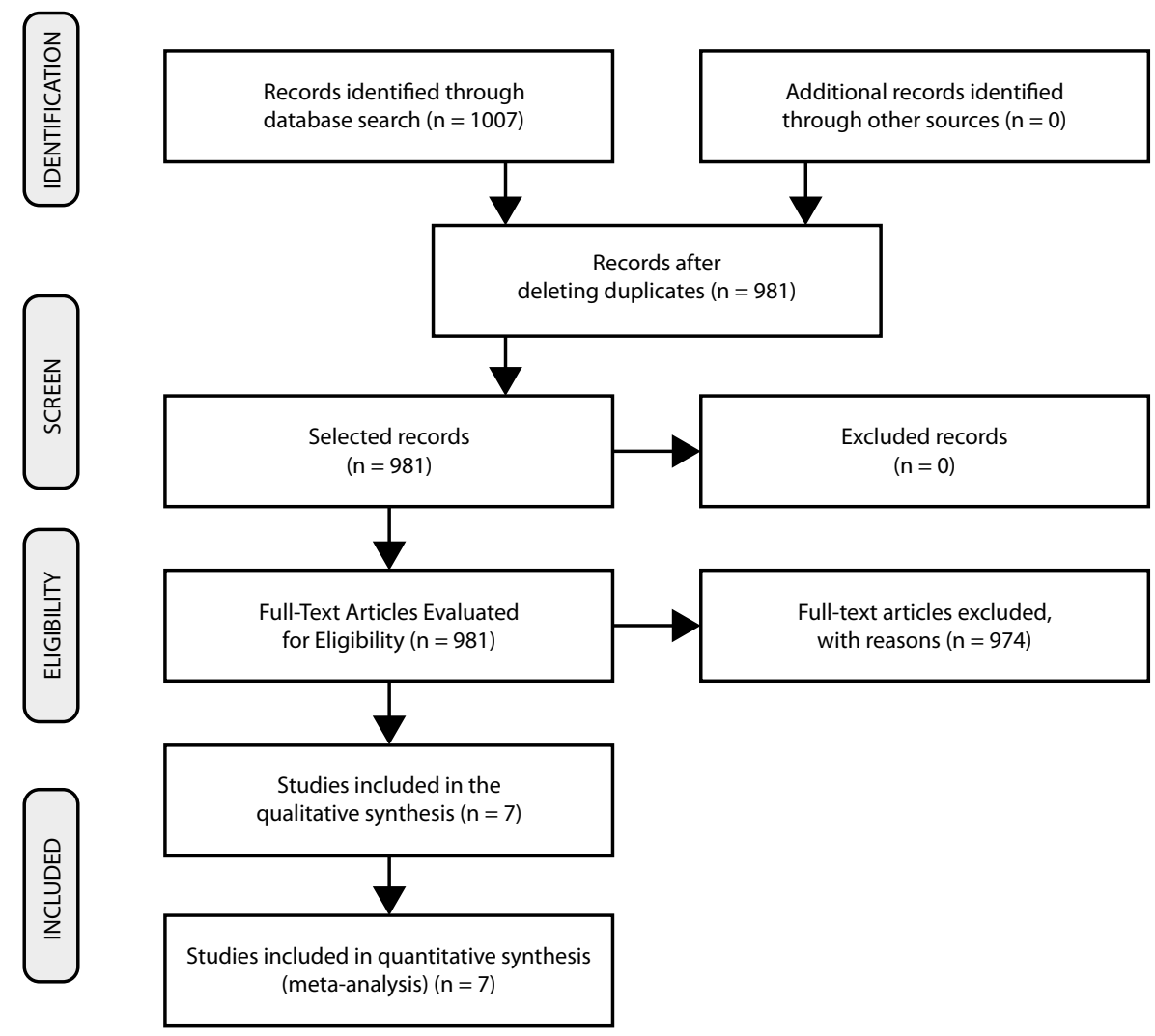

Figure 2 - Figure Prism. Procedure for selection of articles in bibliographic searches

\section{Description of studies}

See Figure 3.

\begin{tabular}{|c|c|c|c|c|c|c|}
\hline $\begin{array}{c}\text { Authors and } \\
\text { year }\end{array}$ & Objective & Sample & Applied intervention & Scales used & $\begin{array}{c}\text { Duration } \\
\text { of the } \\
\text { intervention }\end{array}$ & Results \\
\hline $\begin{array}{l}\text { Phipps S et } \\
\text { al. }^{(13)} \\
2012\end{array}$ & $\begin{array}{l}\text { Efficacy of } \\
\text { complementary } \\
\text { therapies in cancer } \\
\text { patients who have } \\
\text { received a stem cell } \\
\text { transplant. }\end{array}$ & $\begin{array}{l}\mathrm{N}^{*}=171 \text { Age: } \\
\text { between } 6 \\
\text { and } 18 \text { years } \\
\text { old. }\end{array}$ & $\begin{array}{l}\text { Massage technique: } \\
\text { Massage application together } \\
\text { with interventions for the } \\
\text { promotion of health } \\
\text { Areas of application: not } \\
\text { specified }\end{array}$ & $\begin{array}{l}\text { Subscale } \\
\text { Physical Domain } \\
\text { questionnaires } \\
\mathrm{CDI}^{\dagger} \\
\mathrm{PTSDI}^{\ddagger} \\
\mathrm{CHQ}^{\S} \\
\mathrm{BFSC}^{\|} \\
\end{array}$ & 30 Minutes & $\begin{array}{l}\text { Post-stress } \\
\text { Traumatic } \\
\text { Syndrome, Pain and } \\
\text { Depression lowered } \\
\text { in week } 24 \text { after } \\
\text { transplantation }\end{array}$ \\
\hline $\begin{array}{l}\text { Post-White } J \text { et } \\
\text { al. }{ }^{(14)} \\
2009\end{array}$ & $\begin{array}{l}\text { Effects of massage } \\
\text { therapy on reduction of } \\
\text { anxiety, cortisol, fatigue, } \\
\text { nausea and pain in } \\
\text { children with cancer }\end{array}$ & $\begin{array}{l}\mathrm{N}^{*}=17 \\
\text { Between } 1 \\
\text { and } 18 \text { years } \\
\text { old }\end{array}$ & $\begin{array}{l}\text { Massage Technique: } \\
\text { Effleurage, percussive } \\
\text { technique (tapping) } \\
\text { pressures with thumb and } \\
\text { petrissage } \\
\text { Application areas: Back, } \\
\text { legs, arms, stomach / thorax } \\
\text { and face }\end{array}$ & 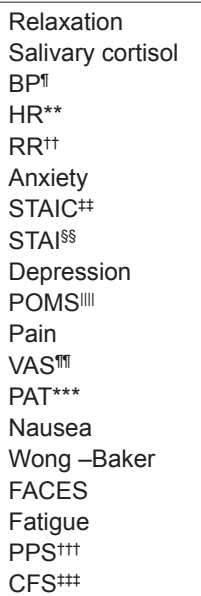 & 30 Minutes & $\begin{array}{l}\text { Improvement of } \\
\text { cardiac rhythm } \\
\text { and respiratory } \\
\text { frequency. No } \\
\text { pain or cortisol } \\
\text { improvement. } \\
\text { Anxiety was } \\
\text { lowered. }\end{array}$ \\
\hline
\end{tabular}




\begin{tabular}{|c|c|c|c|c|c|c|}
\hline $\begin{array}{c}\text { Authors and } \\
\text { year }\end{array}$ & Objective & Sample & Applied intervention & Scales used & $\begin{array}{c}\begin{array}{c}\text { Duration } \\
\text { of the } \\
\text { intervention }\end{array} \\
\end{array}$ & Results \\
\hline $\begin{array}{l}\text { Haun JN et al. }{ }^{(15)} \\
2009\end{array}$ & $\begin{array}{l}\text { To determine the } \\
\text { physiological, } \\
\text { psychological and } \\
\text { viability effects of } \\
\text { the application of } \\
\text { massage therapy in } \\
\text { the pediatric oncology } \\
\text { and haematological } \\
\text { population }\end{array}$ & $\begin{array}{l}\mathrm{N}^{*}=30 \\
\text { Between } 6 \\
\text { months and } \\
17 \text { years old }\end{array}$ & $\begin{array}{l}\text { Massage technique: Swedish } \\
\text { massage (effleurage, } \\
\text { petrissage, percussion, } \\
\text { compression and friction) } \\
\text { Areas of application: hands, } \\
\text { feet, arms, shoulders and } \\
\text { back }\end{array}$ & $\begin{array}{l}\text { STAIC } ¥ \\
\text { CHQ\$ } \\
\text { Wong Baker } \\
\text { FACES }\end{array}$ & 20 Minutes & $\begin{array}{l}\text { Muscular pain } \\
\text { and discomfort } \\
\text { were lowered as } \\
\text { well as respiratory } \\
\text { frequency and } \\
\text { anxiety levels in the } \\
\text { treatment group. }\end{array}$ \\
\hline $\begin{array}{l}\text { Field T et al. }{ }^{(16)} \\
2001\end{array}$ & $\begin{array}{l}\text { Effects of massage } \\
\text { therapy on anxiety, } \\
\text { depression and the } \\
\text { immune system of } \\
\text { children with leukemia }\end{array}$ & $\begin{array}{l}\mathrm{N}^{*}=20 \\
\text { Average age } \\
6.9 \text { years }\end{array}$ & $\begin{array}{l}\text { Massage techniques: } \\
\text { effleurage, circular } \\
\text { movements, fingers, pressure } \\
\text { plus torsion (petrissage). } \\
\text { Areas of application: face, } \\
\text { neck, shoulders, back, } \\
\text { stomach, legs, feet, arms and } \\
\text { hands. In supine and prone } \\
\text { position. Done by parents. }\end{array}$ & $\begin{array}{l}\text { STAIC } ¥ \\
\text { POMSIIII } \\
\text { CBC\&sS }\end{array}$ & 15 Minutes & $\begin{array}{l}\text { Parental anxiety } \\
\text { was lowered. Rise } \\
\text { in white cell and } \\
\text { Neutrophil count. }\end{array}$ \\
\hline $\begin{array}{l}\text { Mazlum S et } \\
\text { al. }{ }^{(17)} 2013\end{array}$ & $\begin{array}{l}\text { To know the } \\
\text { effectiveness of } \\
\text { massage in children } \\
\text { receiving chemotherapy } \\
\text { (effects on nausea and } \\
\text { vomiting) }\end{array}$ & $\begin{array}{l}\mathrm{N}^{*}=70 \\
4 \text { to } 18 \text { years }\end{array}$ & $\begin{array}{l}\text { Massage technique: Swedish } \\
\text { massage: effleurage, } \\
\text { petrissage, friction, } \\
\text { percussive technique } \\
\text { Areas of application: not } \\
\text { specified }\end{array}$ & $\begin{array}{l}\text { BARFIIIIII } \\
\text { VAS } \\
\text { Scale for } \\
\text { vomiting }\end{array}$ & 20 minutes & $\begin{array}{l}\text { Nausea incidence } \\
\text { lowered after } \\
\text { chemotherapy. } \\
\text { Vomits were less } \\
\text { frequent after } \\
\text { chemotherapy. }\end{array}$ \\
\hline $\begin{array}{l}\text { Batalha LM et } \\
\text { al. }{ }^{(18)} 2013\end{array}$ & $\begin{array}{l}\text { To evaluate the } \\
\text { effectiveness of } \\
\text { massage application } \\
\text { in pain relief in } \\
\text { hospitalized children } \\
\text { with cancer }\end{array}$ & $\begin{array}{l}\mathrm{N}^{*}=52 \\
\text { Between } 10 \\
\text { and } 18 \text { years } \\
\text { old }\end{array}$ & $\begin{array}{l}\text { Massage technique: } \\
\text { Pressure with sliding and } \\
\text { circular movements } \\
\text { Areas of application: dorsum- } \\
\text { lumbar, hands, legs and feet }\end{array}$ & 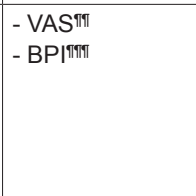 & $\begin{array}{l}20-30 \\
\text { minutes }\end{array}$ & $\begin{array}{l}\text { Pain reduction in } \\
\text { three separate } \\
\text { sessions and } \\
\text { improvement } \\
\text { in children } \\
\text { movements. }\end{array}$ \\
\hline $\begin{array}{l}\text { Mehling WE et } \\
\text { al.(19) } \\
2012\end{array}$ & $\begin{array}{l}\text { To determine the } \\
\text { viability of oriental } \\
\text { massage (acupressure) } \\
\text { in children with } \\
\text { hematopoietic cell } \\
\text { transplants }\end{array}$ & $\begin{array}{l}\mathrm{N}^{*}=23 \\
\text { Between } 5 \\
\text { and } 18 \text { years } \\
\text { old }\end{array}$ & $\begin{array}{l}\text { Massage technique: Swedish } \\
\text { massage and acupressure } \\
\text { Areas of application: in } \\
\text { feet, arms, legs, back and } \\
\text { shoulder girdle for massage. } \\
\text { For acupressure use different } \\
\text { points of the body }\end{array}$ & $\begin{array}{l}\text { - DES } \\
\text { - questionnaires: } \\
\text { - BASES } \\
\text { - Pedt+t } \\
\text { - Peds }\end{array}$ & 20-30 minutes & $\begin{array}{l}\text { No improvements in } \\
\text { pain and nausea. }\end{array}$ \\
\hline
\end{tabular}

*N: Sample size; ${ }^{+}$CDI: The Children`s Depression Inventory; $\neq$PTSDI: Posttraumatic Stress Disorder Reaction Index for the Diagnostic and Statistical Manual of Mental Disorder; §CHQ: Children`s Health Questionnaire; ||BFSC: Benefit Finding Scale for Children; |BP: Blood Pressure; **HR: Heart Rate; †+RR: Respiratory Rate; ¥¥STAIC: The State Anxiety Inventory for Children; §§STAI: State Trait Anxiety Inventory; IIIIPOMS: Profile of Mood States;

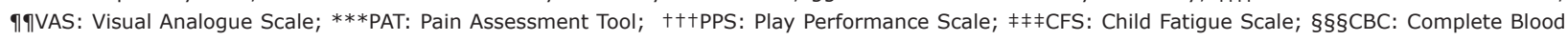
Count; IIIII|BARF: Baxter Animated Rating Face; १११BPI: Brief Pain Inventory; ****DES: Differential Emotions Scale; †††十BASES: The Behavioral Affective and Somatic Scale; $\ddagger \ddagger \neq$ PedsQL: Pediatric Quality of Life Inventory.

Figure 3 - Characteristics of included studies. Badajoz, EX, Spain, 2016

\section{Sociodemographic characteristics}

The size of the sample ranged from $\mathrm{N}=171$, of the study $^{(13)}$ with the larger sample to $\mathrm{N}=17$ of the study ${ }^{(14)}$ with the smallest sample.

The youngest kids(14-15) ages from 1 year and 6 months. In one of the papers ${ }^{(16)}$ the average age was 6.9 years. In the remainder studies, subjects were between 4 and 18 years old(13,17-19).

\section{Intervention and treatment groups}

The application of the treatment was divided in two groups, control and intervention (14-19), except in one of the studies ${ }^{(13)}$ with a control group and two intervention groups. In one of the intervention groups massage therapy and humor is applied and in the other in addition to the above the parents were instructed in massage and relaxation. The intervention consisted of massage applied on the body ${ }^{(13-19)}$.

\section{Techniques}

Most studies used the Swedish massage ${ }^{(14-17,19)}$, applying techniques of effleurage, petrissage, frictions and compressions ${ }^{(13-15,17-19)}$ with moderate pressure. The maneuvers were applied in combination(13-19), predominating effleurage, petrissage and digital kneading $^{(15-16,18)}$. In only one of the studies ${ }^{(16)}$ effleurage was applied on legs, ending with stretching of the Achilles tendon and circular movements with fingers centrifugally. They performed techniques with light pressure $^{(18)}$, moderate ${ }^{(15,17,19)}$ and firm ${ }^{(14)}$.

In some studies ${ }^{(14-15,17)}$ they also use percussive technique(14-15,17), friction ${ }^{(17)}$ and a thousand hands technique(14). 
Others $^{(13,19)}$ added acupressure ${ }^{(19)}$ and interventions for health promotion ${ }^{(13)}$, not specifying the massage technique or place of application.

\section{Areas of application and frequency}

In one of the studies ${ }^{(19)}$ the center of the application was on legs, feet and arms, while others ${ }^{(16)}$ performed a sequence, face, neck, shoulders, back, stomach, legs, feet, arms and hands, and were the only ${ }^{(16)}$ that performed Swedish massage in both decubitus. In the rest it was applied on the back, hands, legs, feet ${ }^{(18)}$, one of them including ${ }^{(14)}$ face and arms. Two investigations ${ }^{(13,17)}$ did not specify the body part.

Interventions in all studies were fifteen ${ }^{(16)}$, twenty ${ }^{(15,17,19)}$ and thirty minutes ${ }^{(13-14,18-19)}$, being carried out in one of the studies ${ }^{(16)}$ by the parents. In the rest by a nurse ${ }^{(18)}$ or a masseur ${ }^{(13-15,17,19)}$ with experience ${ }^{(14-15)}$.

The treatment protocol was: three sessions ${ }^{(17-18)}, 1$ session / day for one month(16),3 sessions / week for 41 days $^{(19)}, 3$ sessions / week for 4 weeks ${ }^{(13)}$ and 4 sessions / week $^{(14)}$.

\section{Type of cancer}

Four studies indicate the types of cancer, being the most frequent $\operatorname{ALL}^{(13-14,16,18)}$, acute myeloid leukemia $(A M L)^{(13)}$, Sarcomas and lymphomas(18), Hodgkin ${ }^{(13)}$, brain tumors ${ }^{(14)}$, Wilms tumor ${ }^{(14)}$ and Ewing sarcoma ${ }^{(14)}$. The rest ${ }^{(14,17,19)}$ was not specified.

\section{Scales}

To measure the effects produced, they used valuation scales ${ }^{(14-18)}$ and questionnaires ${ }^{(13,19)}$. The scales used were:

-Visual Analogue Scale $\mathrm{e}^{(14,17-18)}$

-Wong Baker FACES ${ }^{(14-15)}$

-Brief Pain Inventory ${ }^{(18)}$

-Pain Assessment Tool(14)

-Enumerated scale of $0-3^{(17)}$

-Baxter Animated Rating Face ${ }^{(17)}$

-The State Anxiety Inventory for Children ${ }^{(14-16)}$

-State Trait Anxiety Inventory ${ }^{(14-15)}$

-Lansky`s Play Performance Scale ${ }^{(14)}$

-Profile of Mood States ${ }^{(14,16)}$

-The Children's Depression Inventory ${ }^{(13)}$

-Posttraumatic Stress Disorder Reaction Index for the Diagnostic and Statistical Manual of Mental Disorder(13) -Children `s Health Questionnaire(13,15)

-Benefit Finding Scale for Children ${ }^{(13)}$

The Questionnaires ${ }^{(13,19)}$ were:

-Behavioral Affective and Somatic Scale ${ }^{(19)}$

-PedsQL Cancer Module.9(19)

-The Differential Emotions Scale(19)

-Child Fatigue Scale ${ }^{(13)}$

\section{Results obtained}

Five investigations addressed pain ${ }^{(13-15,18-19)}$, but only three $(13,15,18)$ verified that the massage produces changes on it. One study ${ }^{(18)}$ shows a decrease in pain half an hour after each session. They used massage with pressure with sliding and circular movements using the fingers during 20-30 minutes $^{(18)}$. In one of the studies ${ }^{(18)}$ the authors observed a significant decrease of the pain related to ambulation. Other authors ${ }^{(15)}$ indicate a decrease in muscle pain after Swedish massage in hospitalized and outpatient children with daily sessions on the first and weekly sessions on the second lasting 20 minutes for 4 weeks. A study ${ }^{(13)}$ shows the lasting decrease of the pain, and it does it combining massage and humor therapy. In two studies ${ }^{(14,19)}$ favorable results were not obtained: in one of them ${ }^{(14)}$ children who received chemotherapy and 4 weekly sessions of massage applying effleurage, petrissage, percussive technique and a thousand hands, according to the scale VAS and in the other ${ }^{(19)}$, using the PedsQL Cancer Module questionnaire that obtained a non-statistically significant decrease.

Only in one of the included studies ${ }^{(17)}$, after applying Swedish massage for 20 minutes in three sessions before and 24 hours after chemotherapy, they succeeded in delaying the appearance of both acute nausea and nausea that usually appears after 24-72 hours. In two other investigations it has been observed that combined Swedish massage and acupressure increase the levels of nausea(19) or no changes are seen with respect to their baseline assessment ${ }^{(14)}$.

In one of the studies ${ }^{(13)}$ when performing the massage, in 30-minute sessions over four weeks, it showed a decrease in post-traumatic stress syndrome in 97 of the 171 children in their study. It was maintained from the first day until the last assessment. They did not specify place of application.

Three investigations addressed depression(13,16,19). All agree that the massage intervention produces a decrease, but the application varies. One of the studies ${ }^{(19)}$ combined Swedish massage and acupressure in sessions of 20-30 minutes for 41 days. In another(16) the massage was performed by the parents before going to bed for 15 minutes, for over a month. In the third study(15) it was showed a decrease of depression applying Swedish massage during 20 minutes in children between 6 months and 17 years. The frequency in hospitalized patients was daily and weekly on outpatient clinics.

In a study ${ }^{(16)}$ the authors get a decrease in anxiety according to the STAIC scale in children with ALL. Other authors $^{(14)}$ achieved it by applying effleurage, petrissage and soft passes with the fingertips, during 30 minutes in 
four sessions they managed to decrease the anxiety in patients between 1 and 13 years in the fourth session.

One study ${ }^{(16)}$ addresses the effects on the immune system by applying therapeutic massage throughout the body with the techniques of effleurage, petrissage and circular movements in supine and prone position, observing from the first day an increase of white blood cells and neutrophils, lasting for 30 days.

Two investigations indicate that the respiratory rate decreases using effleurage, petrissage, compressions and frictions ${ }^{(14-15)}$. In one of them ${ }^{(14)}$ they applied massage with cream and in the other ${ }^{(15)}$, the massage is applied by a therapist on hands, feet, arms, shoulders and back for 20 minutes with a cream.

Only one of the studies(14) showed a significant decrease in heart rate at the end of treatment after 4 sessions.

\section{Discussion}

After the analysis we observed that the massage was performed in most cases by masseurs(13-15,17-19) except in one of the studies in which the parents applied $i^{(16)}$. This may suggest that if physiotherapists had performed the interventions the results would have been different.

The participants are aged between 6 months $^{(15)}$ and 18 years old ${ }^{(13-14,18)}$. This age range coincides with those of other investigations ${ }^{(20-22)}$. Although the interpretation must be carried out prudently since in some cases ${ }^{(14,19)}$ the data collection has been done by the parents, and it could have biased the results.

The sample is reduced, 17-52 patients(14-16,18-19), which makes difficult the extraction of significant results, except for two of the investigations ${ }^{(13,17)}$ with samples of 70 and 171 patients respectively.

One of the papers ${ }^{(18)}$ showed a decrease in pain in ambulation in children between 10 and 18 years while in other studies a decrease of muscle pain has been observed after the application of Swedish massage for 20 minutes $^{(15)}$ or how improvement is maintained in the long term ${ }^{(13)}$. Despite these 3 previous studies show an improvement in pain, it is achieved using different techniques, and different treatment regimens can be established to obtain equal benefits.

The decrease of pain in this study ${ }^{(18)}$ could be due to the techniques applied in the dorsum-lumbar area, legs and feet. Greater oxygenation and muscle relaxation occurs here ${ }^{(9,23)}$ which allows indirectly improving ambulation.

In another of the analyzed articles ${ }^{(15)}$ the application of the massage was performed in hospitalized and ambulatory patients. Those hospitalized patients who received daily sessions perceived a greater level of relaxation and less sensation of pain. On the other hand, the assessment through observational scales in children under two years of age was performed by the parents, which may have led to misinterpretation because they were not familiar with the evaluation instruments. These benefits can be achieved in both inpatients and outpatients and by using different techniques such as Swedish massage and the technique of circular movements with fingers. This is concurrent with other studies $^{(10-11,24)}$ not present in this review. In that sense, they have used Swedish massage in adult patients with bone metastases ${ }^{(11,24)}$ or therapeutic massage in adult palliative care patients ${ }^{(10)}$, decreasing pain.

Taking into account what has been stated by some authors ${ }^{(25)}$ we thought that having performed two sessions, half an hour and 24 hours before the application, the effects of massage could have influenced acute and delayed nausea. This decrease could be due to the indirect activation of the nervous system ${ }^{(26)}$ counteracting the secretion of serotonin, produced by chemotherapy ${ }^{(25)}$, leading to reduced nausea and vomiting. This benefit is not showed by other studies included ${ }^{(19)}$ in this review using Swedish massage and acupressure, although applying the same number of sessions ${ }^{(17)}$ failed to demonstrate a decrease in nausea and vomiting. The massage(19) was performed on feet, arms legs, back and scapular waist, however, one of the works ${ }^{(17)}$ did not specify the areas of application so we can not consider the place of application of massage as one of the reasons why there were no benefits.

The literature (27) shows that one of the techniques used for the reduction of anxiety in children with cancer is the massage. Several investigations have demonstrated a decrease of anxiety applying Swedish massage in adult patients with $\mathrm{AML}^{(28)}$ or in patients with coronary interventions ${ }^{(29)}$.

These results coincide with some of the studies analyzed ${ }^{(14-15)}$. The first ${ }^{(15)}$ uses Swedish massage while the second ${ }^{(14)}$, only matches the previous research ${ }^{(15)}$ in two of the techniques, effleurage and petrissage. We can consider that they are the most suitable to reduce anxiety. The reduction in one of the research ${ }^{(14)}$ occurs in patients between 1 and 13 years, especially after the fourth session. We thought that the decrease in the fourth session could have happened because the effects of the massage were more evident than during the first sessions and the patients were more relaxed, improving their mood. With respect to the difference according to age, we consider that using different scales of evaluation can influence the obtaining and interpretation of the results. 
In one of the works ${ }^{(16)}$ the authors show that by applying various massage techniques in children with ALL before bedtime for 30 days, neutrophils and white blood cells increase. This may be due to performing several techniques in different positions covering a larger area and therefore greater benefits. Another factor that could influence might be the form of application, according to medical evidence ${ }^{(9)}$ whe performing the massage centrifugally stimulation is achieved. Therefore, we could consider that the combination of these factors improves blood flow, increasing blood volume, and thus reaching the stimuli received to the marrow to improve the production of blood cells(16). Massage therapy could be considered as a complementary technique to maintain the immune system under optimum conditions.

As studies(30-31) conclude in the need of the oncological children patients to receive additional types of treatment devoid of side effects and with beneficial effects for their health, among them is the massage. There is a need for greater training of professionals ${ }^{(31)}$ in this type of therapy as well as more studies to show the effects of it.

More recent studies(32) corroborate the results of this review. There is preliminary evidence of efficacy in children's massage to reduce pain and anxiety derived from intrathecal therapy or aspiration of bone marrow. This being the only investigation found regarding the subject matter in the period between 2014 and 2107.

Thus the limitations of the study stem from the paucity of studies showing the efficacy of this therapy in patients affected by cancer as well as the scarcity of the sample in the studies analyzed with so small sample sizes results cannot be extrapolated to the total of the population of children with cancer.

\section{Conclusion}

Based on published studies, the effects of therapeutic massage in children with cancer receiving chemotherapy and other treatments show a decrease in pain, nausea, vomiting, posttraumatic stress, depression and anxiety and an increase in white blood cells and neutrophils.

Further research is needed to observe benefits, establish protocols and extrapolate results, to improve the quality of life of these patients.

\section{References}

1. De la Torre I, Cobo MA, Mateo T, Vicente LI. Cuidados enfermeros al paciente oncológico. Málaga: Vértice; 2008. 292 p.
2. Rivera-Luna R, Shalkow-Klincovstein J, Velasco-Hidalgo L, Cárdenas-Cardós R, Zapata-Tarrés M, Olaya-Vargas A, et al. Descriptive epidemiology in Mexican children with cancer under an open national public health insurance program. BMC Cancer. [Internet]. 2014. [cited April 13, 2015]; 14: 790. Available from: http://bmccancer. biomedcentral.com/articles/10.1186/1471-2407-14-790 3. Siegel R, Naishadham D, Jemal A. Cancer statistics for Hispancis/Latinos, 2012. CA Cancer] Clin. [Internet].2012. [cited April 13, 2015]; 62 (5): 283-98. Available from: http://www.cancer.org/acs/groups/content/@research/ documents/document/acspc-046405.pdf

4. Pacheco M, Madero L. Oncología pediátrica. Psicooncología. [Internet]. 2003. [Acceso 12 Abril 2015]; 1: 107-16. Disponible en: http://www.seom. org/seomcms/images/stories/recursos/sociosyprofs/ documentacion/psicooncologia/numero1_volo/ articul09.pdf

5. Cooper SL, Brown PA. Treatment of pediatric acude lymphoblastic leukemia. Pediatr Clin North Am. [Internet]. 2015. [cited April 13, 2015]; 62 (1): 6173. Available from: http://www.ncbi.nlm.nih.gov/pmc/ articles/PMC4366417/pdf/nihms662731.pdf

6. Ju HY, Hong CR, Shin HY. Advancements in the treatment of pediatric acute leukemia and brain tumor - continuous efforts for $100 \%$ cure. Korean J Pediatr. [Internet]. 2014. [cited April 12, 2015]; 57 (10): 4349. Available from: http://www.ncbi.nlm.nih.gov/pmc/ articles/PMC4219945/pdf/kjped-57-434.pdf

7. Fritz S. Fundamentos del masaje terapéutico. Barcelona: Paidotribo; 2001. 500 p.

8. Rodríguez JA. De friegas y masoterapia: Consideraciones históricas sobre la evolución del masaje. En: Torres M, Salvat I, editores. Guía de masoterapia para fisioterapeutas. Madrid: Panamericana; 2006 .p. 3-25.

9. Vázquez J. Manual profesional del masaje. Badalona: Paidotribo; 2009. p. 1-21.

10. Falkensteiner $M$, Mantovan F, Müller $I$, Them C. The use of massage therapy for reducing pain, anxiety, and depression in oncological palliative care patients: a narrative review of the literature. ISRN Nurs. [Internet].2011. [cited April 11, 2015]; 929868. Available from: http://www.ncbi.nlm.nih.gov/pmc/ articles/PMC3168862/pdf/NURSING2011-929868.pdf 11. Jane SW, Wilkie DJ, Gallucci BB, Beaton RD, Huang HY. Effects of a full-body massage on pain intensity, anxiety, and physiological relaxation in Taiwanese patients with metastatic bone pain: a pilot study. J Pain Symptom Manage. [Internet].2009. [cited April 11, 2015]; 37 (4): 754-63. Available from: http://www.jpsmjournal.com/ article/S0885-3924(08)00561-7/fulltext 
12. Escala PEDro [Internet]. [Acceso 13 Abril 2015]. Disponible en: http://www.pedro.org.au/spanish/ downloads/pedro-scale/

13. Phipps S, Peasant C, Barrera $M$, Alderfer MA, Huanq Q, Vannatta K. Resilience in children undergoing stem cell transplantation: results of a complementary intervention trial. Pediatrics. [Internet]. 2012. [cited April 11, 2015]; 129 (3): 762-70. Available from: http:// www.ncbi.nlm.nih.gov/pmc/articles/PMC3289525/pdf/ peds.2011-1816.pdf

14. Post- White J, Fitzgerald M, Savik K, Hooke MC, Hannahan AB, Sencer SF. Massage therapy for children with cancer. J Pediatr Oncol Nurs. [Internet]. 2009. [cited April 11, 2015]; 26 (1): 16-28. Available from: https://www.researchgate.net/profile/Kay_Savik/ publication/23655253_Massage_Therapy_for_Children_ With_Cancer/links/0912f510fe9561c023000000.pdf

15. Haun JN, Granham-Pole J, Shortley B. Children with cancer and blood diseases experience positive physical and psychological effects from massage therapy. Int ] Ther Massage Bodywork. [Internet].2009. [cited April 13, 2015]; 2 (2): 7-14. Available from: http:// www.ncbi.nlm.nih.gov/pmc/articles/PMC3091462/pdf/ ijtmb-2-2-7.pdf

16. Field T, Cullen C, Diego M, Hernandez- Reif M, Sprinz $P$, Beebe $K$, et al. Leukemia immune changes following massage therapy. J Bodyw Mov Ther. [Internet]. 2001. [cited April 13, 2015]; 5 (4): 271-4. Available from: http://www.sciencedirect.com/science/article/pii/ S1360859201902281

17. Mazlum S, Chaharsoughi NT, Banihashem A, Vashani $H B$. The effect of massage therapy on chemotherapyinduced nausea and vomiting in pediatric cancer. Iran J Nurs Midwifery Res. [Internet]. 2003. [cited April 11, 2015]; 18 (4): 280-4. Available from: http://www.ncbi. nlm.nih.gov/pmc/articles/PMC3872861/

18. Batalha LM, Mota AA. Massage in children with cancer: effectiveness of a protocol. J Pediatr. [Internet]. 2013. [cited April 12, 2015];89 (6): 595-600. Available from: http://ac.els-cdn.com/S0021755713001654/1s2.0-S0021755713001654-main.pdf?_tid=1e3b636254f4-11e6-904d-00000aab0f27\&acdnat $=1469731993$ b339159ff86ca7340e15330bd8950ac1

19. Mehling WE, Lown EA, Dvorak CC, Cowan MJ, Horn BN, Dunn EA, et al. Hematopoietic cell transplant and use of massage for improved symptom management: results from a pilot randomized control trial. Evid Based Complement Alternat Med. [Internet]. 2012. [cited April 13, 2015];1-9. Available from: http://www.ncbi. nlm.nih.gov/pmc/articles/PMC3292254/pdf/ECAM2012450150.pdf

20. Revuelta- Iniesta R, Wilson ML, White $K$, Stewart L, McKenzie JM, Wilson DC. Complementary and alternative medicine usage in Scottish children and adolescents during cancer treatment. Complement Ther Clin Pract. [Internet]. 2014. [cited April 13, 2015]; 20 (4): 197-202. Available from: http://www.ctcpjournal. com/article/S1744-3881(14)00040-1/pdf

21. Bishop FL, Prescott P, Chan YK, Saville J, Von Elm E, Lewith GT. Prevalence of complementary medicine use in pediatric cancer: a systematic review. Pediatrics [Internet]. 2010. [cited April 13, 2015];125 (4): 768-76. Available from: http://www.ncbi.nlm.nih.gov/pubmed/20308209

22. Valadares MT, Mota JA, de Olivera BM. Palliative care in pediatric hematological oncology patients: experience of a tertiary hospital. Rev Bras Hematol Hemoter. [Internet]. 2014. [cited April 13, 2015]; 36 (6): 4038. Available from: http://www.ncbi.nlm.nih.gov/pmc/ articles/PMC4318475/pdf/main.pdf

23. Han JH, Kim MJ, Yang HJ, Lee YJ, Sung YH. Effects of therapeutic massage on gait and pain after delayed onset muscle soreness. J Exerc Rehabil. [Internet]. 2004. [cited April 12, 2015]; 10 (2): 136-40. Available from: http:// www.ncbi.nlm.nih.gov/pmc/articles/PMC4025548/pdf/ jer-10-2-136-15.pdf

24. Toth M, Marcantonio ER, Davis RB, Walton T, Kahn JR, Phillips RS. Massage therapy for patients with metastatic cancer: a pilot randomized cotrolled trial. J Altern Complement Med. [Internet]. 2013. [cited April 13, 2015]; 19 (7): 650-6. Available from: http:// www.ncbi.nlm.nih.gov/pmc/articles/PMC3700435/pdf/ acm.2012.0466.pdf

25. Feeney K, Cain M, Nowak AK. Chemotherapy induces nausea and vomiting-prevention and treatment. Aust Fam Physician. [Internet]. 2007. [cited April 11, 2015]; 36 (9): 702-6. Available from: http://www. uptodate.com/contents/prevention-and-treatment-ofchemotherapy-induced-nausea-and-vomiting-in-adults 26. Fritz S. Fundamentos del masaje terapéutico. Barcelona: Paidotribo; 2001. 500 p.

27. Thrane S. Effectiveness of integrative modalities for pain and anxiety in children and adolescents with cancer: a systematic review. J Pediatr Oncol Nurs. [Internet]. 2013. [cited April 13, 2015]; 30 (6): 32032. Available from: http://www.ncbi.nlm.nih.gov/pmc/ articles/PMC4109717/pdf/nihms577633.pdf

28. Taylor AG, Snyder AE, Anderson JG, Brown CJ, Densmore JJ, Bourguignon C. Gentle massage improves Disease and treatment related symptoms in patients with Acute Myelogeneus Leukemia. J Clin Trials. [Internet]. 2014. [cited April 13, 2015]; 4: 1-18. Available from: http://www.ncbi.nlm.nih.gov/pmc/ articles/PMC4266937/pdf/nihms597751.pdf

29. Babaee S, Shafiei Z, Sadeghi MM, Nik AY, Valiani M. Effectiveness of massage therapy on the mood patients after open-heart surgery. Iran J Nurs Midwifery Res. 
[Internet]. 2012. [cited April 11, 2015]; 17 (2 Suppl 1):

120-4. Available from: http://www.ncbi.nlm.nih.gov/ pmc/articles/PMC3696961

30. Gottschling S, Meyer S, Längler A, Scharifi G, Ebinger $F$, Gronwald B. Differences in use of complementary and alternative medicine between children and adolescents with cancer in Germany: a population based survey. Pediatr Blood Cancer. 2014;61(3):488-92. doi: 10.1002/pbc.24769

31. Roth M, Lin J, Kim M, Moody K. Pediatric oncologists' views toward the use of complementary and alternative medicine in children with cancer. J Pediatr Hematol. Oncol. 2009;31(3):177-82. doi: 10.1097/ MPH.0b013e3181984f5a.

32. Çelebioğlu A, Gürol A, Yildirim ZK, Büyükavci M. Effects of massage therapy on pain and anxiety arising from intrathecal therapy or bone marrow aspiration in children with cancer. Int J Nurs Pract. [Internet]. 2015. [cited March 7, 2017];21(6):797-804. Available from: https://www.ncbi.nlm.nih.gov/pubmed/24689780 Creative Commons (CC BY).

This license lets others distribute, remix, tweak, and build upon your work, even commercially, as long as they credit you for the original creation. This is the most accommodating of licenses offered. Recommended for maximum dissemination and use of licensed materials. 